\title{
Final Pleistocene and Early Holocene at Sitio do Meio, Piauí, Brazil: Stratigraphy and comparison with Pedra Furada
}

\author{
Giulia Aimola ${ }^{1}$, Camila Andrade ${ }^{2}$, Leidiana Mota ${ }^{3}$, Fabio Parenti ${ }^{1}$ \\ 1. Istituto Italiano di Paleontologia Umana, Rome, Italy. Email: Aimola: giuliaimola@gmail.com; Parenti: \\ scriptoriumparentii@gmail.com \\ 2. Museu Nacional - UFRJ, Rio de Janeiro, Brazil. Email: camorim.andrade@gmail.com \\ 3. independent researcher. Email: leidiana.mota@gmail.com
}

\begin{abstract}
:
Sitio do Meio, in southern Piaui, Brazil, is the second most important rock shelter presenting fully Pleistocene dates and artefacts after Pedra Furada. Despite the anthropogenic origin of Pedra Furada artefacts having been questioned, SDM has a better chance of being accepted by the scientific community because of the absence of the most relevant stone breaking agents in this kind of site, i.e. waterfalls. This paper presents a critical review of the history of excavations (1980-2000), stratigraphy, chronology, and the archaeological content of the site (sector 2). At least 98 stone tools have been identified and described, all of them being older than 12,500 BP, i.e. belonging to the Upper Pleistocenic phase of Pedra Furada 3, as defined in the close reference site. The lithic industry of Serra Talhada phase (Lower Holocene) is also presented and compared with Paleoindian sites of NorthEastern and Central Brazil.
\end{abstract}

Keywords: Upper Pleistocene; Lower Holocene; Brazil; lithic industries; excavations; radiocarbon dating; first peopling of the Americas

\section{Resumé:}

Le Sitio do meio, dans le Piaui méridional (Brésil) est le deuxième abri sous roche de la région ayant livré des dates pléistocènes en dehors du site de la Pedra Furada. L'article présente une révision critique des fouilles (1980-2000), la chronostratigraphie et le contenu archéologique du secteur 2. Une centaine d'outils lithiques sont décrits, ils sont plus anciens de $12,5 \mathrm{ka}$ BP et correspondent à la phase Pléistocène Pedra Furada 3 définie dans le site éponyme de référence. On présente aussi l' industrie lithique de la phase Serra Talhada (Holocène ancien) en la comparant aux industries paléoindiennes du Nord-Est et du centre du Brésil.

Mots-clés: Pléistocène supérieur; Holocène inférieur; Brésil; industries lithiques; fouilles; radiocarbone

Published by the School of History, Classics and Archaeology, University of Edinburgh ISSN: 2055-0472. URL: http://journals.ed.ac.uk/lithicstudies/

This work is licensed under a Creative Commons Attribution 2.5 UK: Scotland License. 


\section{Introduction}

For a long time Pleistocene peopling of the Americas has been the focus of possibly the most copious and inconclusive debate in the field of prehistory. In the last twenty years, the issues on the top spot of this important but yet unsolved chapter of human and natural history range from the genetic background of the ancestral stock(s) which originated the first Americans (Anderson \& Gillam 2000, Perego et al. 2009), with the associated issue of the number and timing of peopling events (Lanata et al. 2008), the palaeogeographic and palaeoclimatic conditions for such events (Pitblado 2011), as well as the "routes" of peopling (Bryan \& Ghrun 2003, Dillehay 2008). At the very core of these hypothesis, theories or simply conjectures is - in the ultimate level - the humble nature of artefacts and the stratigraphic context of each site.

Brazilian lowlands have been for almost two decades at the centre of action for the Southern continent because of the presence of several sites with radiocarbon dates $>12,000$ BP and the debated nature of the associated cultural material. Since 1980, in South-Eastern Piaui, the franco-brazilian team led by Niéde Guidon conducted many research projects on rock-art chronology (Guidon 1985), "pre-Clovis" archaeological sites (Guidon \& Delibrias 1986, Guidon \& Arnaud 1991), as well as palaeontological (Guérin \& Faure 2008) and palaeoenvironmental data (Chaves et al. 2008). The longest chronological sequence in the region is Boqueirão da Pedra Furada (BPF) rock-shelter which has been published in details (Parenti 2001, Santos et al. 2003) after an harsh debate (Meltzer et al. 1994, Parenti et al. 1996). The final Pleistocene layers at BPF (PF 3) show a slight evolution in lithic tool-kit,

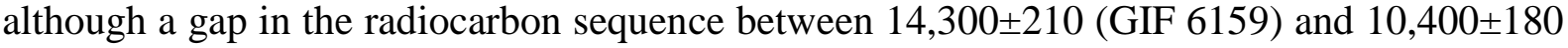
(GIF 5862) has been recorded. This gap, as shown below, is partially represented in another rockshelter, named Sitio do Meio (SDM), located in Figure 1 in relation with the reference site of Pedra Furada.

In this paper we present the available data on past excavations at SDM, obtained on the basis of published data (Guidon \& Andreatta 1980, Guidon \& Pessis 1993, Pinheiro de Melo 2000) and four unpublished dissertations (Aimola 2008, Andrade 2010, Mota 2010, Pinheiro De Melo 2007), focusing both on the existence of cultural remains in the final Pleistocene and on the significance of lithic tool-kit in early Holocene, in the context of the prehistory of North-Eastern Brazil (Martin 1997).

\section{Regional setting: Serra da Capivara National Park, Sítio do Meio rockshelter and the archaeological excavations}

Southern Piaui is dominated by the contrast between the wide pre-Cambrian plain and the Palaeozoic plateau of Piaui-Maranhão basin. The bulk of more than 1,300 sites actually recorded in the Serra da Capivara National Park and its surroundings are sandstone shelters with rock paintings, mainly dated to early and mid-Holocene. As usual in Northern Brazil, the shelters are mostly created by differential erosion of the cuesta cliffs, as in the close $(1,500 \mathrm{~m})$ reference site of Pedra Furada, incised in a silty layer interbedded in the Silurian sandstone of Serra Grande formation. 

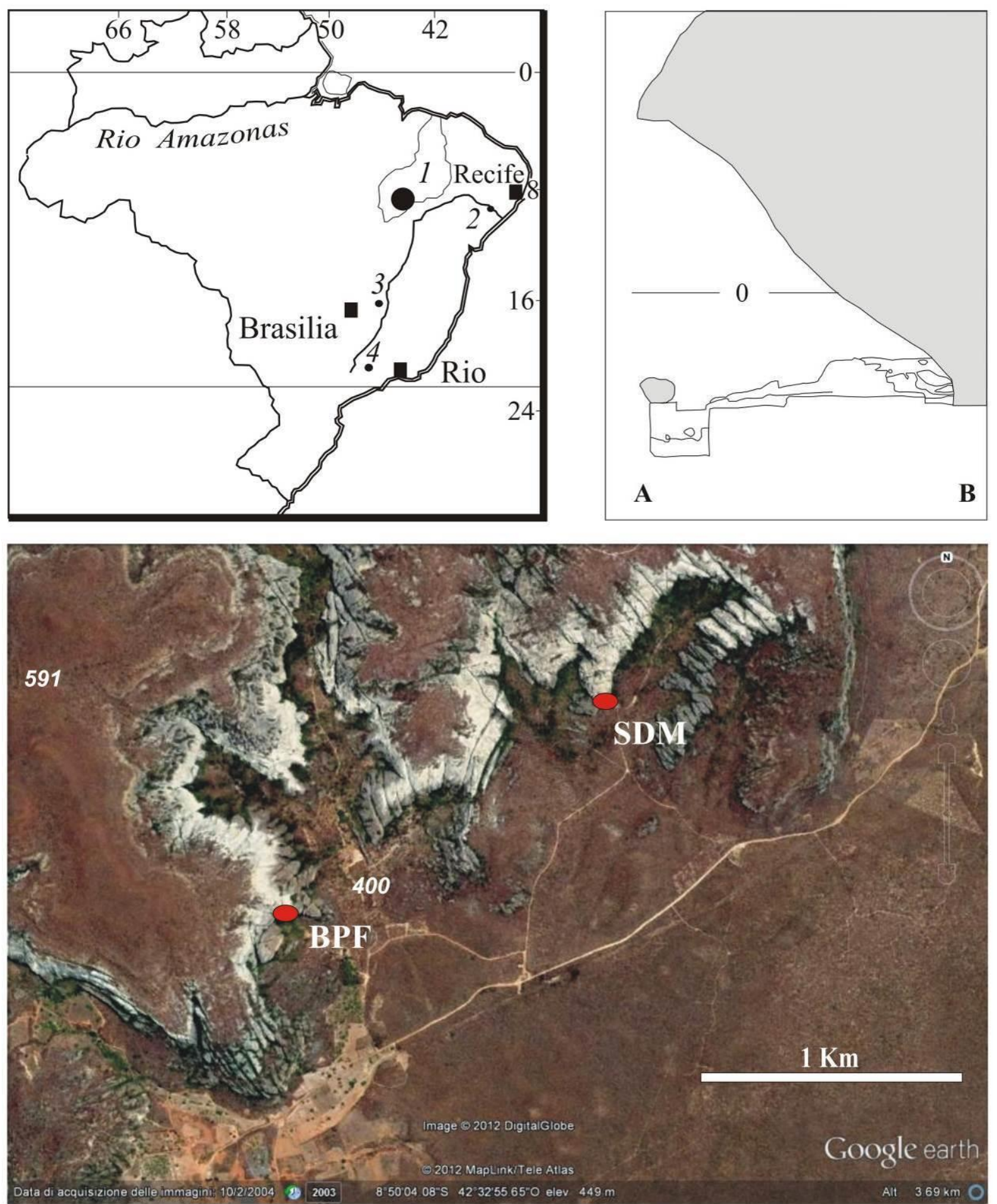

Figure 1. Position of sites: Sitio Do Meio (SDM) and Boqueirão da Pedra Furada (BPF.). Aerial image from Google Earth (2014).

At SDM the available surface is defined by an impressive talus of collapsed sandstone blocks, noticed as soon as the site was discovered (Guidon \& Andreatta, 1980). Behind the blocks is the most protected portion of the sheltered area $\left(86 \mathrm{~m}^{2}\right)$, with red-painted panels of Serra Talhada tradition on the wall and engravings on some blocks (Cisneiros 2008). During past excavations hundreds of these blocks have been removed, their length ranging from 0.4 to $18 \mathrm{~m}$. The shelter is $64 \mathrm{~m}$ long, its width ranging from two to 17 meters due to the irregularities of the sandstone wall. The maximum elevation of the roof is about $29 \mathrm{~m}$, which 
allows the most intense rainstorms penetrate the outer part of the site, as in BPF (See Figure 1). The conventional limit between "inner" and "outer" sector of the site adopted in past excavation reports is almost parallel to the drip line (See Figure 2). Collapsed blocks were found in both sectors, excavations in the inner part often had to be interrupted because of the presence of such blocks. The deposition of these is the main agent of the filling of rockshelters in semi-arid landscapes, as documented also in the case of BPF. In the majority of shelters in Serra da Capivara area, the filling is usually not older than lower Holocene, but in some cases it has been protected from erosion, which was stronger in the final Pleistocene moister conditions.

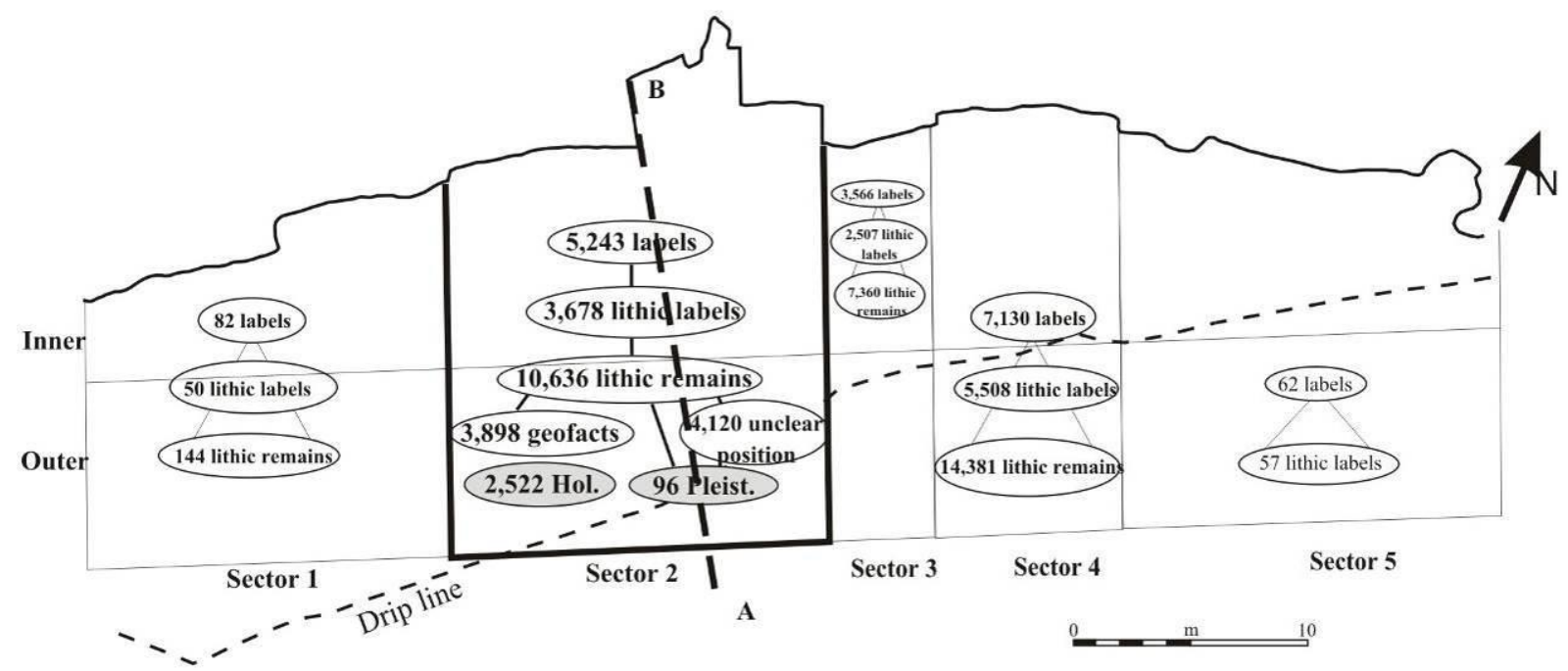

Figure 2. Site plan with labels and artifacts per sector, comprising both inner and outer part.

The interpretation of data from Sitio do Meio is a difficult task, mainly because of the complicated history of its excavations (sectors and materials are represented in Figure 2). About $80 \%$ of the upper layers of the site have been excavated, but the lowermost Pleistocene units have been unearthed only in the central part of the sheltered area. More recent soundings have been conducted in 2012 by Eric Boeda and co-workers in the eastern portion of the shelter (Boeda et al. 2013, fig. 24.1).

From 1973 to 2000, six field campaigns have been undergone (listed in Table 1), all coordinated by Niéde Guidon, but in collaboration with several field-leaders, in different sectors or -sometimes- in the same sector, but employing different data recording techniques and with different scientific goals. The most difficult task the archaeologists faced in this site was the recognition, definition and removing of each -supposed-sedimentary unit. This is mainly because the lateral discontinuity of sandy lenses in rock-shelters, an old nightmare for prehistoric archaeologists (Bordes 1975), but also because of the abundance and heterogeneity of fallen blocks. For these reasons, the similar numbers observed in the field reports of SDM does not have any stratigraphic meaning and does not imply any correspondence or correlation. Therefore, each specific object or structure considered in this study has been submitted to a careful verification of its position before its inclusion in the database with a firm chronological attribution.

In order to reconstruct the sequence of excavations, to have a reliable synopsis of the stratigraphy and to clearly identify the Pleistocene units of past excavations, one of us (GA) conducted a detailed philological reading of the documentation available in FUMDHAM archives in 2008, proceeding as follows: 1) control of the dip of sedimentary units recorded in the sections; 2) synopsis of field notebooks; the most complete for stratigraphic remarks and 
topographic details are those of 1978 and 1980 campaigns, which served as a basis to reconstruct a stratigraphy with the dip of each excavation campaign.

Table 1. Excavation campaigns at SDM: 1978-2000

\begin{tabular}{ccllllll}
\hline Year & Days & Leader & Survey equipment & Dimensions & $\mathrm{M}^{3}$ & $\begin{array}{l}\text { Progressive } \\
\mathrm{M}^{3}\end{array}$ & Sectors \\
\hline 1978 & 13 & Guidon & Grid, transit level & $5 \times 5 \times 2.5$ & 62.5 & 62.5 & $\begin{array}{l}2: \text { abcde } \\
\text { squares }\end{array}$ \\
1980 & 14 & Guidon & Grid, transit level & $3 \times 5 \times 4$ & 60 & 122.5 & $\begin{array}{l}2: \text { fgh } \\
\text { squares }\end{array}$ \\
& & & & & & 4 \\
1980 & & Guidon & Grid, transit level & $4 \times 3 \times 2.1$ & 25.4 & 147.9 & 4 \\
1991 & 47 & Team & Grid, transit alidade & $2 \times 7 ; 2 \times 3$ & 20 & 167.9 & 2 \\
1991 & & Team & Grid, transit alidade & $2 \times 2 ; 5 \times 2$ & 14 & 181.9 & 4 \\
1992 & 12 & Team & Grid, transit alidade & $\begin{array}{l}4.5 \times 3 \times 5 ; 9.2 \times 2 \times \\
2 ; 3 \times 2 \times 5.6\end{array}$ & 135.5 & 317.36 & 2 \\
1993 & 6 & Team & Grid, transit alidade & $5 \times 4 \times 2.4$ & 48 & 365.36 & 4 \\
2000 & $?$ & Pinheiro & Total station & $5 \times 5 \times 1.6$ & 41.25 & 406.61 & 3 \\
2000 & $?$ & Pinheiro & Total station & $5 \times 4 \times 1.6$ & 32 & 438.61 & 4 \\
\hline Tot & $>92$ & & & & & 2210.64 & \\
\hline
\end{tabular}

The site was discovered in 1973; in March 1978, a small trench measuring one by two meter and 1.1 meter deep was opened, stopped by sandstone blocks. In July 1978, excavations were extended up to an area of $5 \times 7 \mathrm{~m}$, with the same depth in each square, except on $\mathrm{F}$ and $\mathrm{G}$ sectors, because of the presence of collapsed blocks. Two radiocarbon dates were obtained

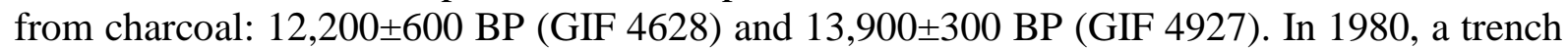
of $3 \times 4 \mathrm{~m}$ was dug, one meter deep. At the end of this campaign, an assemblage of 79 lithics (30 on siltstone small slabs) was collected and another two dates were obtained: $12,440 \pm 230$ (GIF 5403) and 14,300 \pm 40 (GIF 5399).

Although yielding interesting dates from the Pleistocene-Holocene boundary, the excavations at SDM were interrupted for over a decade, due to the much older chronology observed at BPF. In fact, the quite old Pleistocene dates obtained there in 1978 and 1980 called for larger surface excavations from 1982 onwards. It is not unreasonable to say that from 1984 to 1988, BPF drew almost any effort by Guidon's team, with one of us (FP) coordinating the main campaigns from 1987 to 1988. Sitio do Meio excavations were resumed in June 1991 in order to try to confirm the very old dates obtained from BPF (Figure 3 ). In those days, the huge sandstone blocks at the entrance of the shelter still protected the sections of older excavations, the sequence of which was - obviously - used as reference for the new ones. Modern surface was completely surveyed, and the site was subdivided in inner and outer parts and in 5 sectors: sectors 1, 3, 5 remained preserved and new research was undertaken in sectors 2 and 4, the same ones of the earlier excavations. After the removal of larger blocks, in sector $2(17 \times 16 \mathrm{~m})$ and $4(17 \times 8 \mathrm{~m})$ a new metrical grid system was established and excavation was (supposedly) conducted by natural layers (french décapages), and each décapage was subdivided in excavation phases. Due to the granulometrical homogeneity combined with a lateral discontinuity of the sediment, sometimes this recording system lead to a lack of correspondence between the excavations units (décapage or phase) and the sedimentary bodies effectively recorded in final sections. In sector 2 (comprising an area of $272 \mathrm{~m}^{2}$, the largest one), a surface collecting of re-worked remains was undertaken: postcontact ware, lithics, bovids and equids remains, charcoal and modern feces. Below the disturbed sediment, the first true décapage was performed: a rich lithic industry, charcoal, ochre and two fragments of painted sandstone were recovered; moreover, a fireplace was identified and excavated. Two trenches for stratigraphic control were opened in this sector. Afterwards the entire sector was excavated and all blocks removed. Although charcoal and 
lithics were recovered in the lower layers, no datings were obtained in this campaign. In sector 4, two trenches were opened when the excavated surface was at 4th phase of the second décapage, in order to attain the same level of 1980 trenches (named - unfortunately - as in sector 2, "Trench 1" and "2", 1991). In 1993, the bottom in sector 4 was finally reached and the outer portion of sector 2 was explored with a trench which was perpendicular to the sandstone wall. Below another collapsed block, more archaeological layers with charcoal fragments and lithics were discovered. On July 29th, the excavations reached the sandstone at the bottom, just below a sterile layer of fine sand, with comminuted (probably natural)

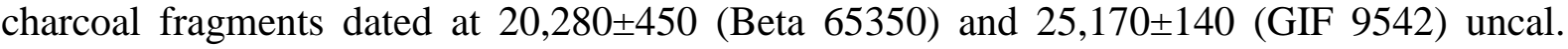
years BP. During the 1993 campaign almost the entire sector 4 was excavated; in its Northeastern part, at $1.3 \mathrm{~m}$ from the top-soil, a fireplace was uncovered and dated at $8,800 \pm 60$ (Beta 47494) uncal. years BP, and it was not excavated. Despite the loss of some of field notes, we know that one hearth was found, dated at 9,200 060 (BETA 65856) uncal. years BP and (apparently) associated with a polished axe (Guidon \& Pessis 1993).

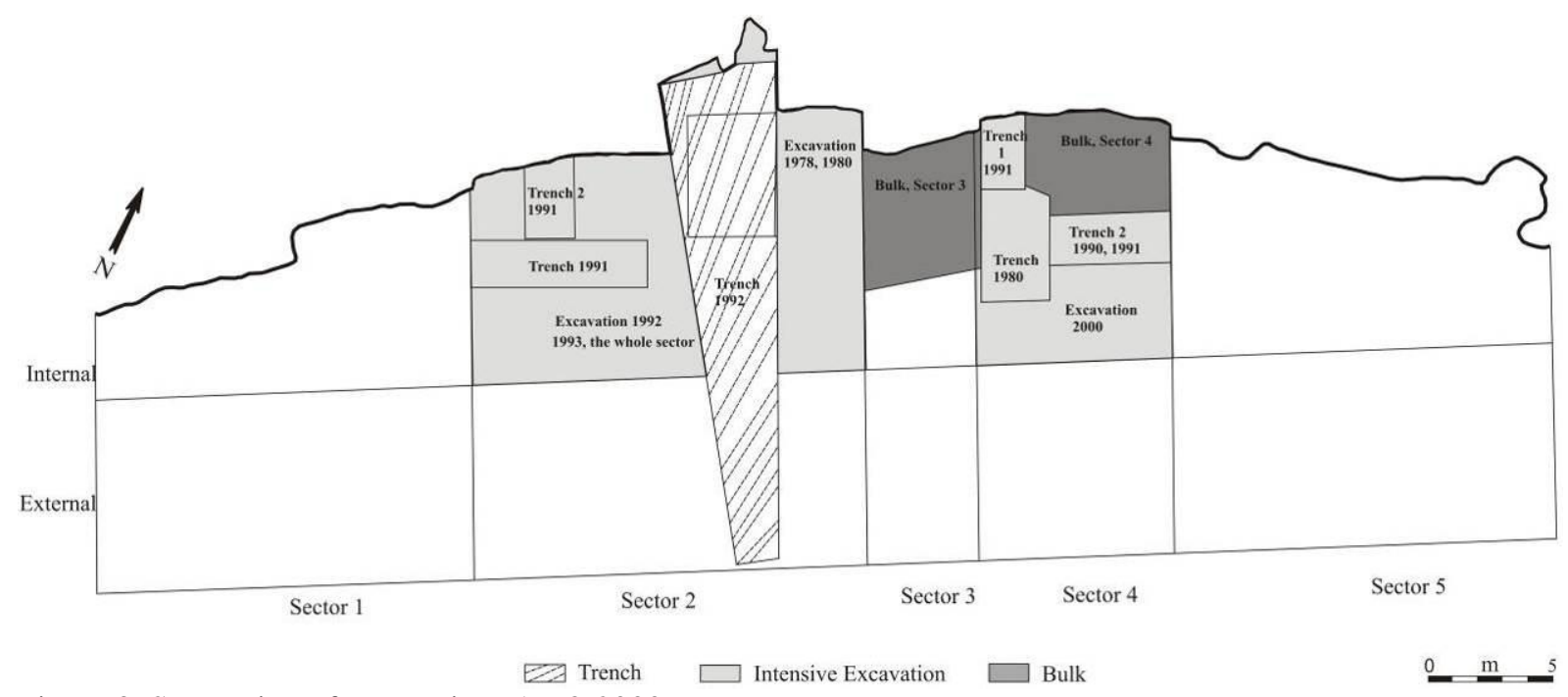

Figure 3. Succession of excavations 1978-2000.

Excavations were interrupted at an (archaeologically) "sterile" layer at $2.4 \mathrm{~m}$ of depth. In 1999 and 2000, P. Pinheiro de Melo carried out new research in sector 4 where the preserved blocks were excavated till the bedrock, providing six fireplaces, the precise position of them, however, is unclear. Sector $3(6 \times 5 \mathrm{~m})$ was also excavated in order to link the previous sections of sectors 2 and 4; but the term décapage was, in this case, referred to natural strata, i.e. units of variable thickness, instead of regular excavation phases inside each stratum. After the usual cleaning of modern sediments, 12 fireplaces were unearthed. One of them is morphologically remarkable and dated to 8,805 \pm 50 (LY 10138) uncal. years BP. (Discussed further in Section 5.) Just below, another structure with sandstone slabs and an ochre plaquette with a string of graminaceous seeds were recovered along with human teeth from a four to nine years-old individual. This funerary structure was dated at 8,920 5 50 (LY 10134) uncal. years BP. The excavation continued until the in situ sandstone, but the available documentation is not very informative and, therefore, it will not considered here. All 14C dates are listed in Table 2.

In 2012 a new excavation project took place at SDM, leaded by Boeda and co-workers (Boeda et al. 2013). In this paper, the short chapter dedicated to SDM (p. 457-459) is mainly devoted to lithic technology and is not as informative as necessary in order to understand the relationship between new and old excavations. In the few lines devoted to the stratigraphy of the shelter, it seems that Boeda and co-workers adopted the stratigraphic synopsis proposed 
by of Pinheiro de Melo (2000), without assessing its reliability: A- Holocene unit, B- undated, $\mathrm{C}$-half a meter dated at the bottom between 23,000 and 25,000 BP. It is exactly this subdivision that we carefully re-considered and checked in the Master thesis of one of us (Aimola, 2008), concluding that, because the lack of homogeneity of excavation techniques and documentation, it is not as firm as proposed. Starting from this stratigraphically unfirm terrain, Boeda and co-workers, on the basis of a small trench, announce the "surprising discovery" of a stone blocks structure "filled with a large number of small cobbles". The issue of stone structures at SDM is well known and it has been considered since a long time; in FUMDHAM deposits are stored 517 sandstone blocks or slabs and 238 quartz cobbles from 57 recorded structures which, according to field notes (when available) are described as clearly of anthropic origin, sometime polished, with percussion marks and, often, associated with charcoal. But also for these important remains the previous documentation is cryptic, even if in this case almost all structures have been drawn. One of us (CA) has provided a careful revision of this documentation for her dissertation (Andrade, 2010). Moreover, one of these structures, a fireplace romantically called "stonehenge", is the most expressive example of B3 structure type of existing classification (Parenti 2001, p. 116; fig. 11); it is on display at the Museu do Homem Americano. May be Boeda and co-workers did not gain access to the available reports on this crucial matter (Pinhero, 2000, 2007; Andrade 2010) as long as to the many shelves in FUMDHAM deposits full with sandstone blocks and cobbles from SDM structures.

\section{Stratigraphy and chronology}

Below the disturbed surface sediments $(30-40 \mathrm{~cm})$, the sub-horizontal Holocene layers are composed mainly by colluvial sands and quartz pebbles with sandstone or siltstone plaquettes from the wall. Based on sections available at FUMDHAM files, on notes by J. dos Santos (Santos 2007: 93) and on personal field observations, the sediment can be described as follows, from bottom to top: I) Palaeozoic sandstone of Serra Grande formation; II) very thin layer of fine sands, thickening close to the outer portion of the shelter; III) sand with rounded quartzitic cobbles and siltstone fragments; IV) fallen heterometric sandstone blocks; V) small gravel with angular and sub-angular quartz pebbles in matrix of poorly sorted medium sand. Units III-IV are visible in Figure 4.

Throughout the 1978-2000 campaigns, a total 29 radiocarbon dates have been obtained, all from charcoal. Among these dates, only 16 (13 in sector 2 ) have a precise position and will be considered here (shaded in Table 2). In any case, beneath the 12,640 210 uncal. years BP (GIF 9541), -2.40 m below datum, all samples resulted in fully Pleistocene dates, therefore all the associated material from sector 2 will be retained in this analysis. At the very bottom of the sequence a date of 25,170 \pm 140 (GIF 9542) uncal. years BP was obtained from a charcoal fragment from the unit 2, a possible fluvial sediment thicker in the outer part of the shelter, not associated with any artifact. This is the terminus post quem for the archaeological presence at the site (Figure 5).

\section{Lithic industry}

According to our revision of FUMDHAM collections, sector 2 has yielded a gross total of 10,636 inventoried lithic remains, collected in 3,678 topographic points, according to which a label number was attributed (Figure 2). The vast majority of these remains are splitted pebbles of quartz without any intentional flaking evidence (collected either for comparative purposes or because they present evidence of heating) or sandstone slabs that belonged to purported fireplaces or other structures. We should note, however, some sampling bias between different field seasons: in 1978 and 1980 only purported artifacts had been 
recovered, whereas in following campaigns all lithic remains were collected. Out of these 10,636 remains, 96 are from Pleistocene and 2,522 from Holocene layers (here defined by elevation), 3,851 were classified as geofacts by Pinheiro De Melo (2007) and the remaining 4,167 have uncertain stratigraphic position and therefore were excluded from this analysis. Moreover, sector 2 - the largest one - has been extensively excavated and roughly $130 \mathrm{~m}^{2}$ are outside the drip-line and, because of this, more exposed to the intrusion of geofacts from the outer stream.

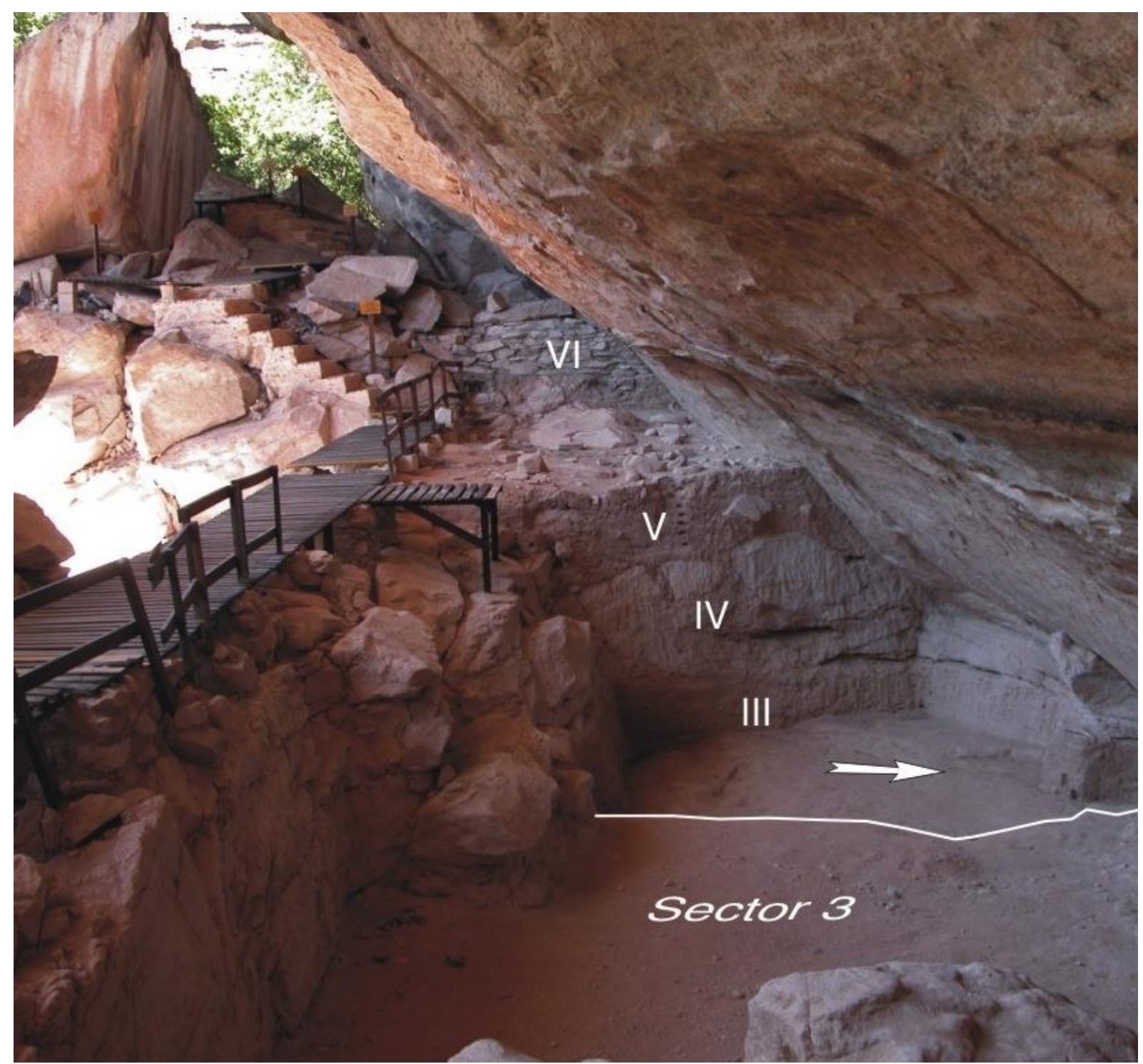

Figure 4. Sector 2 and main section, looking West. (Photo by G. Aimola.)

Given this sampling context, the selection of lithics, both from Pleistocene and Holocene units, has been conducted on the base of the natural gravitative fractures observed in BPF site (Parenti 2001: 135-150). This decision took into account the fact that both, topography and sedimentology at SDM and BPF share similar conditions: both sites lay at the bottom of the cuesta and are located between two canyons; SDM, however, is different because: 1) it does not present any active talus of quartz cobbles and pebbles originated by near waterfalls as BPF (however SDM was probably flooded before the first block collapse); 2) the outline of cuesta in front of SDM is convex and narrow, unlike that of BPF, which is large and concave; this probably leads to a lesser water volume during rainfalls; 3 ) finally, differently from BPF 
with its East-West average dip of $10^{\circ}$, sedimentary units at SDM have a sub-horizontal dip; this means that the entry of pebbles inside the drip-line is much more uncommon than in the outer portion of the shelter, as documented by the fine matrix of sedimentary unit $\mathrm{V}$ (see Figure 4). In sum, we included in this study any flaked pebble with at least two adjacent flake-scars $>10 \mathrm{~mm}$ and any flake with striking platform angle $<90^{\circ}$.

Table 2. 14C dates from SDM, shaded considered dates with a precise position. Calibration with Calpal

\begin{tabular}{|c|c|c|c|c|c|c|c|}
\hline Dates & $+/-$ & Calibration & $\mathbf{N}^{\circ} \mathbf{L a b}$. & Label & Year & Sector & Elevation \\
\hline 97 & 0,7 & & AMS- Ua18143 & 29386 & 1991 & 2 & Top \\
\hline 7.240 & 45 & $6.216-6.009$ & LY 10137 & 58758 & 2000 & 3 & \\
\hline 8.100 & 90 & $7.411-6.669$ & GIF 9409 & 41069 & 1992 & 2 & \\
\hline 8.760 & 100 & & GIF 8988 & $34302 / 34340$ & 1991 & 2 & \\
\hline 8.800 & 60 & & Beta 47494 & 39603 & 1992 & 2 & $-1,3$ \\
\hline 8.804 & 53 & $8.200-7.655$ & LY 10138 & 58026 & 2000 & 3 & \\
\hline 8.920 & 50 & $8.260-7.925$ & LY 10134 & $59201 / 59226$ & 2000 & 3 & \\
\hline 8.925 & 55 & $8.262-7.923$ & LY 10136 & 58530 & 2000 & 3 & \\
\hline 8.960 & 70 & & Beta 47493 & $38219 / 38210$ & 1992 & 4 & $-1,64$ \\
\hline 9.080 & 60 & $10.370-10.330$ & Beta 148099 & $59244 / 59261$ & 2000 & 3 & \\
\hline 9.110 & 60 & & LY 10141 & $59663 / 59724$ & 2000 & 4 & $-2,12$ \\
\hline 9.110 & 80 & 8.342-7.982 & GIF 9407 & $40664 / 40663$ & 1992 & 2 & $-1,60$ \\
\hline 9.150 & 60 & $10.480-10.205$ & Beta 133792 & $50225 / 50226$ & 1999 & 4 & \\
\hline 9.200 & 60 & & Beta 65856 & $41542 / 41540$ & 1993 & 4 & $-2,05$ \\
\hline 9.270 & 100 & $8.584-8.063$ & GIF 9408 & 40758 & 1992 & 2 & $-1,67$ \\
\hline 9.400 & 60 & & GIF 9027 & 36837 & 1991 & 2 & \\
\hline 9.450 & 70 & & Beta 65349 & 41278 & 1993 & 2 & \\
\hline 9.826 & 55 & $9.345-9.220$ & LY 10135 & $59181 / 59481$ & 2000 & 3 & \\
\hline 10.110 & 55 & $9.993-9.361$ & LY 10139 & 58275 & 2000 & 3 & \\
\hline 12.200 & 600 & & GIF 4628 & 2618 & 1978 & 2 & Lev. V \\
\hline 12.440 & 230 & & GIF 5403 & 45 & 1980 & 2 & Lev. XV \\
\hline 12.640 & 210 & $13.595-12.289$ & GIF 9541 & 40961 & 1992 & 2 & $-2,41$ \\
\hline 12.870 & 40 & $13.553-12.941$ & GIF 9540 & 40959 & 1992 & 2 & $-2,57$ \\
\hline 13.100 & 50 & $13.905-13.338$ & GIF 9410 & 40904 & 1992 & 2 & \\
\hline 13.180 & 130 & & LY 6094 & 40952 & 1992 & 2 & $-2,51$ \\
\hline 13.900 & 300 & & GIF 4927 & 2623 & 1978 & 2 & Lev. VI \\
\hline 14.300 & 400 & & GIF 5399 & 83 & 1980 & 2 & Lev. XVIII \\
\hline 20.280 & 450 & & Beta 65350 & $41302 / 41304$ & 1993 & 2 & $-4,91$ \\
\hline 25.170 & 140 & & GIF 9542 & 41145 & 1993 & 2 & $-5,88$ ext. \\
\hline
\end{tabular}

The distribution of the 96 confirmed Pleistocene artifacts of sector 2 is: three choppers, 23 cores , 39 flakes, eight retouched pieces, and 23 fragments (see Figures 6, 7, 8, \& 9). All raw materials are from local origin: quartz and quartzite (66\%) and - interestingly - the softer siltstone (32\%). The absence of chalcedony and flint in final Pleistocene layers has already been described in BPF and it represents one of the most intriguing archaeological problems in this region (Parenti 2001). No clear hammerstones have been recovered from the Pleistocene units. Core tools (choppers + cores) presented an average of 3.9 flake scars, (compared to only 2.3 at BPF), pointing, along with a remarkable number of flakes, to a possible function of SDM as flaking stand or - at least in sector 2 - to the presence of a lithic workshop. Flaking is quite expedient also at SDM as in the Pleistocene layers of BPF, because cores have no prepared striking platforms and flakes have mostly (38\%) cortical butts. Ten retouched tools have been recorded: three choppers and seven flake tools. 


\section{PEDRA FURADA}

\section{SITIO DO MEIO}

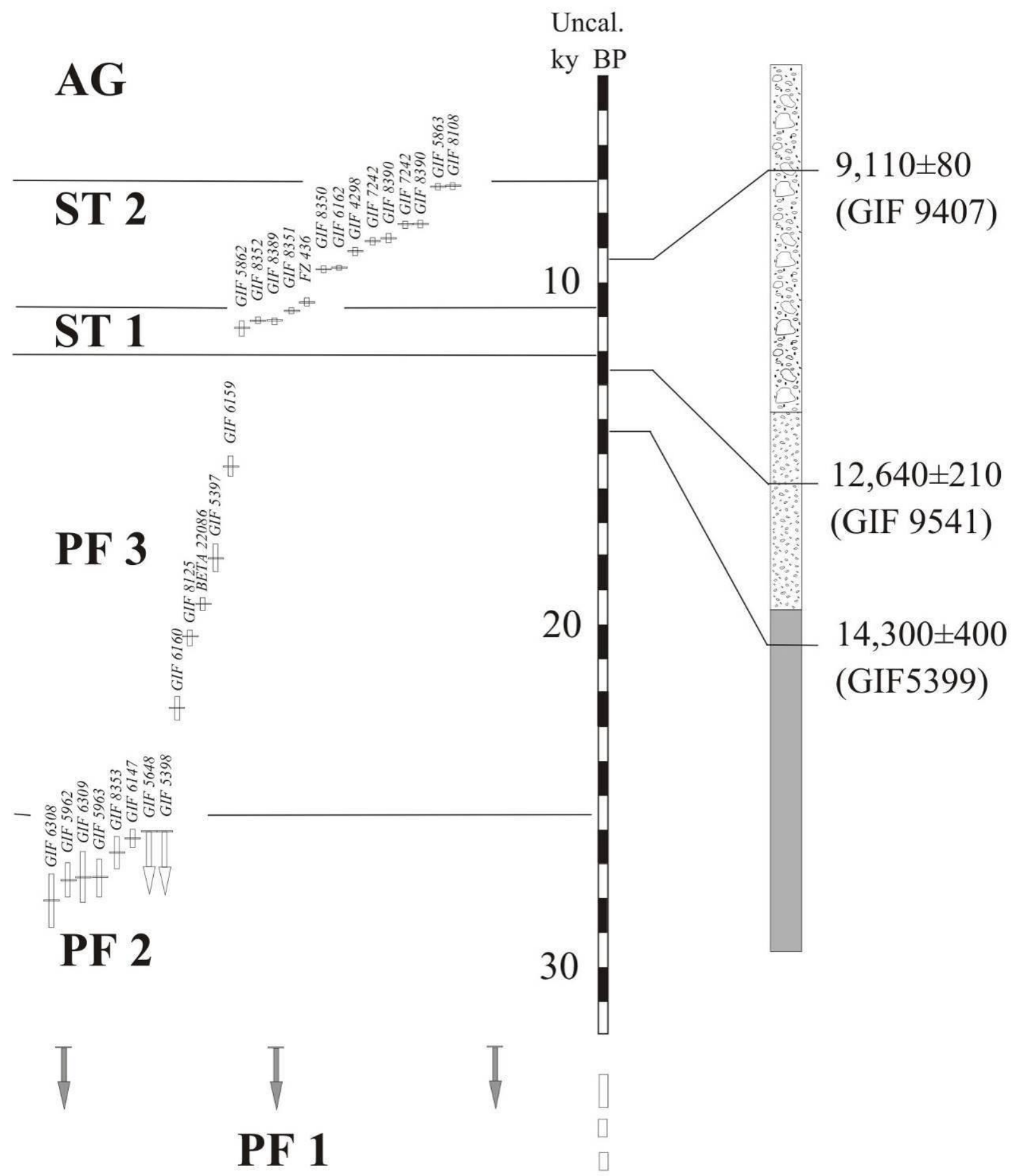

Figure 5. Stratigraphy and chronology of SDM, compared with BPF. 


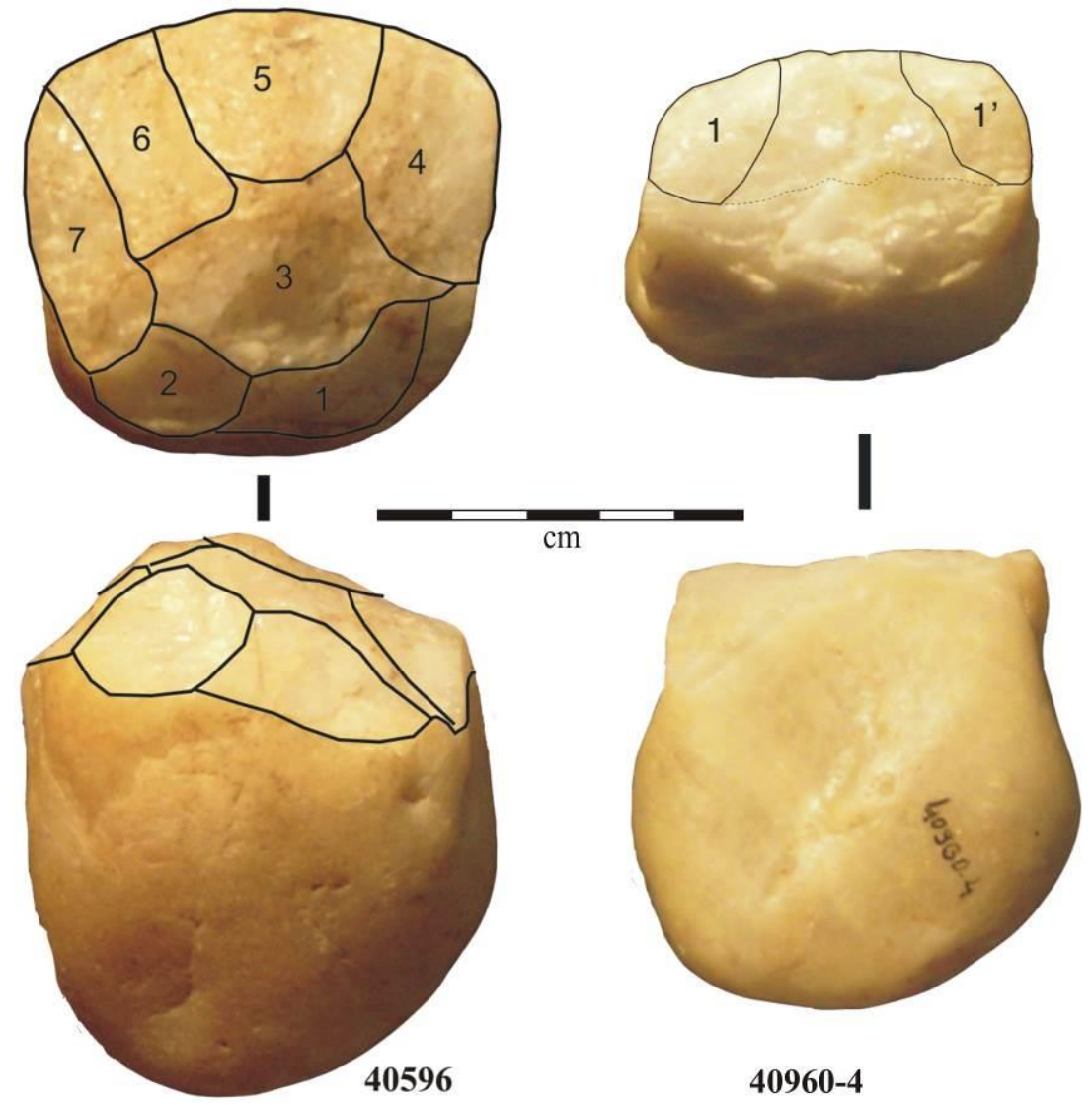

Figure 6. Core tools on quartz pebbles from Pleistocene layer of Sitio do Meio, Pedra Furada 3 phase, older than uncal. 12,640 BP. Numbers refer to FUMDHAM inventory. (Photo by G. Aimola.)

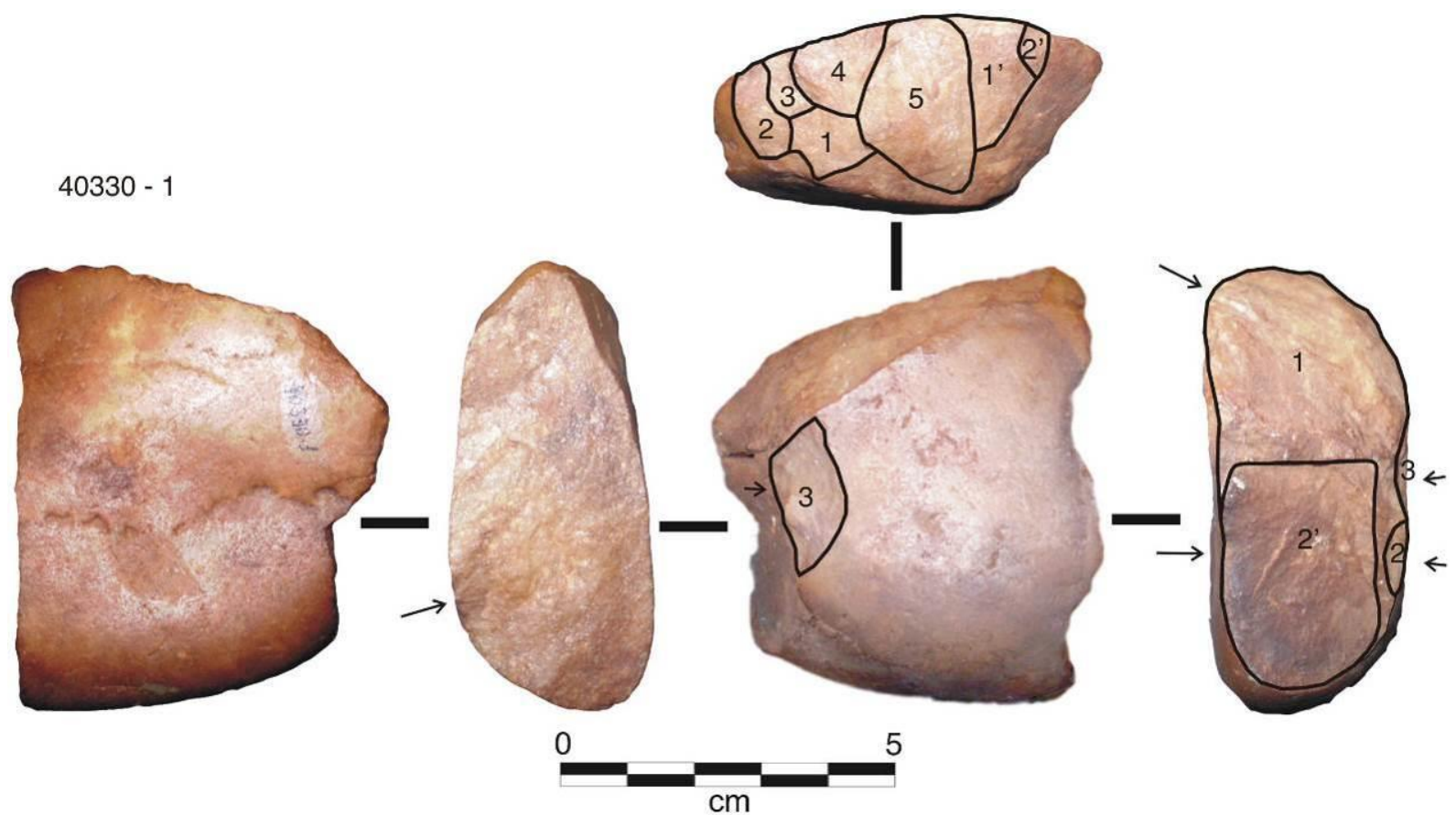

Figure 7. Core on quartz pebbles from Pleistocene layer of Sitio do Meio, Pedra Furada 3 phase, older than uncal. 12,640 BP. Note the high number of flake-scars. (Photo by G. Aimola.) 

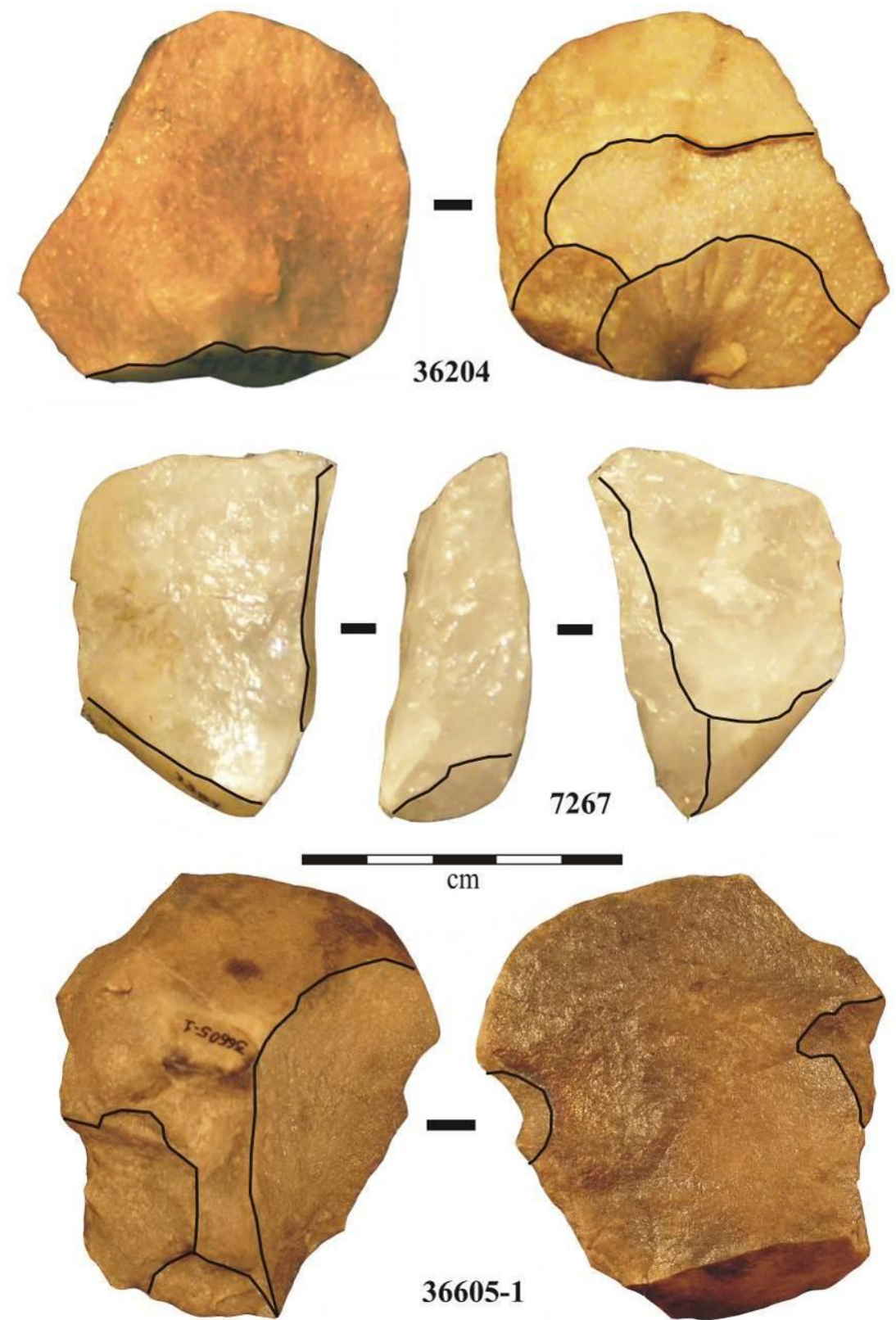

Figure 8. Flakes in quartz and quartzite from Pleistocene layer of Sitio do Meio, Pedra Furada 3 phase, older than uncal. 12,640 BP. Numbers refer to FUMDHAM inventory. (Photo by G. Aimola.)

In the Holocene units of sector 2, 2,522 lithic artifacts have been recovered (sampled in Figure 10), all from the inner portion, in sedimentary units comprised between 9,400 \pm 60 (GIF 9027) and 8,100 \pm 90 (GIF 9409) uncal. years BP, subdivided as follows: two hammerstones, 29 choppers $(1,1 \%), 207$ cores $(8,2 \%), 579$ flakes $(23 \%), 1,549$ chunks and small flakes (42\%). Quartz and quartzite, locally available, sum up to $95 \%$, with some artifacts made on silicified sandstone (1\%), chalcedony (2\%) and siltstone (2\%) (Figure 10). The 207 cores present an average weight of about $200 \mathrm{~g}$ and they retain 6.5 flake-scars each, almost twice of the observed in the Pleistocene layers. Flakes have mostly cortical butts $(61,3 \%)$, but plane $(36,2 \%)$, facetted $(0,35 \%)$, and punctiform butts $(1,6 \%)$ were also observed. Eleven flakes have been made by bipolar technique. 

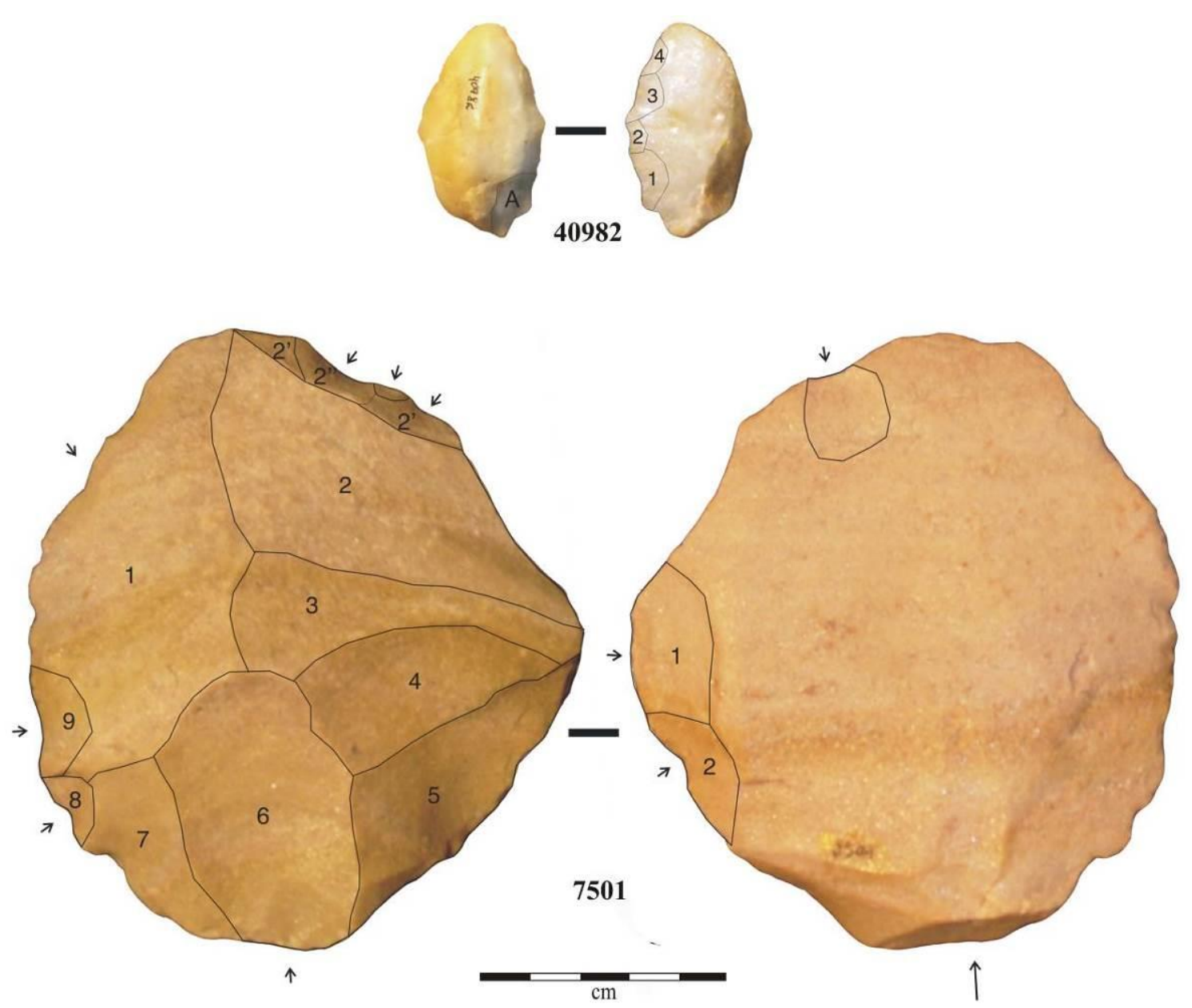

Figure 9. Flakes in quartz and quartzite from Pleistocene layer of Sitio do Meio, Pedra Furada 3 phase, older than uncal. 12,640 BP. Numbers refer to FUMDHAM inventory; retouched pieces: 40982 end-scraper in quartz; 7501: retouched flake in siltstone. (Photo by G. Aimola.)

In such rich deposits as the ones observed during the lower Holocene in Brazilian Northeast, morphological typology still makes sense, mainly for comparative purposes. For this reason we have organized the 82 SDM Holocene retouched artifacts according to the type-list previously adopted for BPF: 1) half of the artifacts (40) were made from flakes, mainly quartzitic flakes; 2) core tools sum up to $35 \%$ 3) only one limace is present; this is a completely retouched unifacial scraper traditionally considered as the reference tool for the lower Holocene in Brazilian Planalto (Lourdeau 2010). It is worth noting that only five tools were made from chalcedony, the prized raw material from which the majority of finished tools have been usually obtained in the rock-shelters toolkit of Southern Piaui. The majority of small flakes have been struck from quartz and quartzite, meaning a greater use of endogenous rocks in comparison to the BPF Holocene layers.

\section{Stone structures, paintings, palynological and faunal remains}

A total of 57 structures, including fireplaces, cairns and lithic workshops, have been recorded at SDM, but reliable documentation is available for only 10 stone structures from sector 4 and five structures from sector 2 (all structures from sector 2 were dated). Structures were made mainly of small fallen sandstone slabs and quartz cobbles. The majority of such structures has no clear borders and do not show any evident difference in their surface as observed in BPF. However, some of the structures are impressive, clearly structured hearths (as the one presented in Figure 11) or - sometimes - possible funerary cairns. Remarkably, 
the dating of one structure $\left(\mathrm{n}^{\circ} 1 / 18,1992\right)$ gave a final Pleistocene age: $13,180 \pm 130$ (LY 6094).
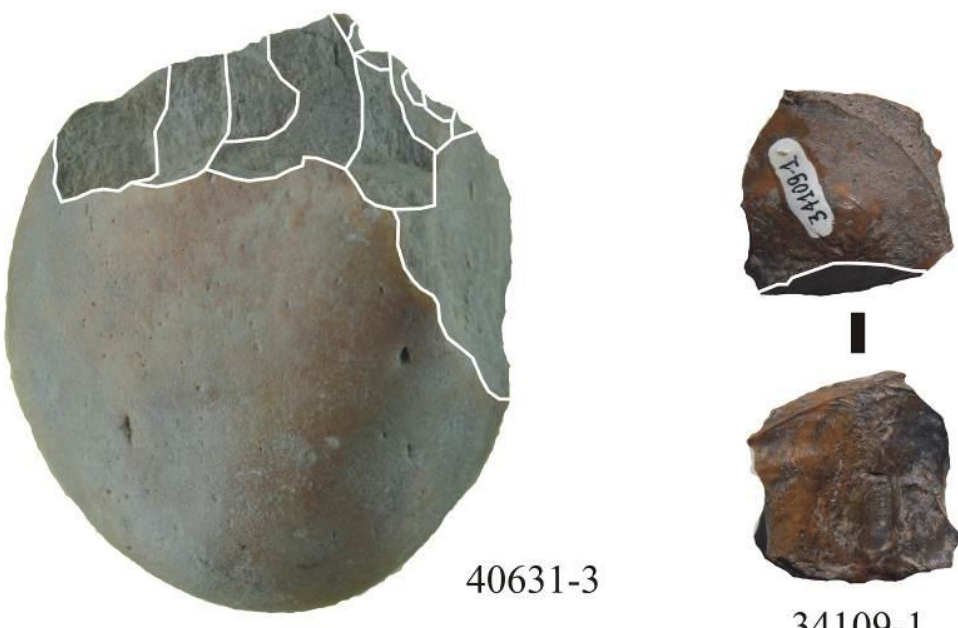

34109-1
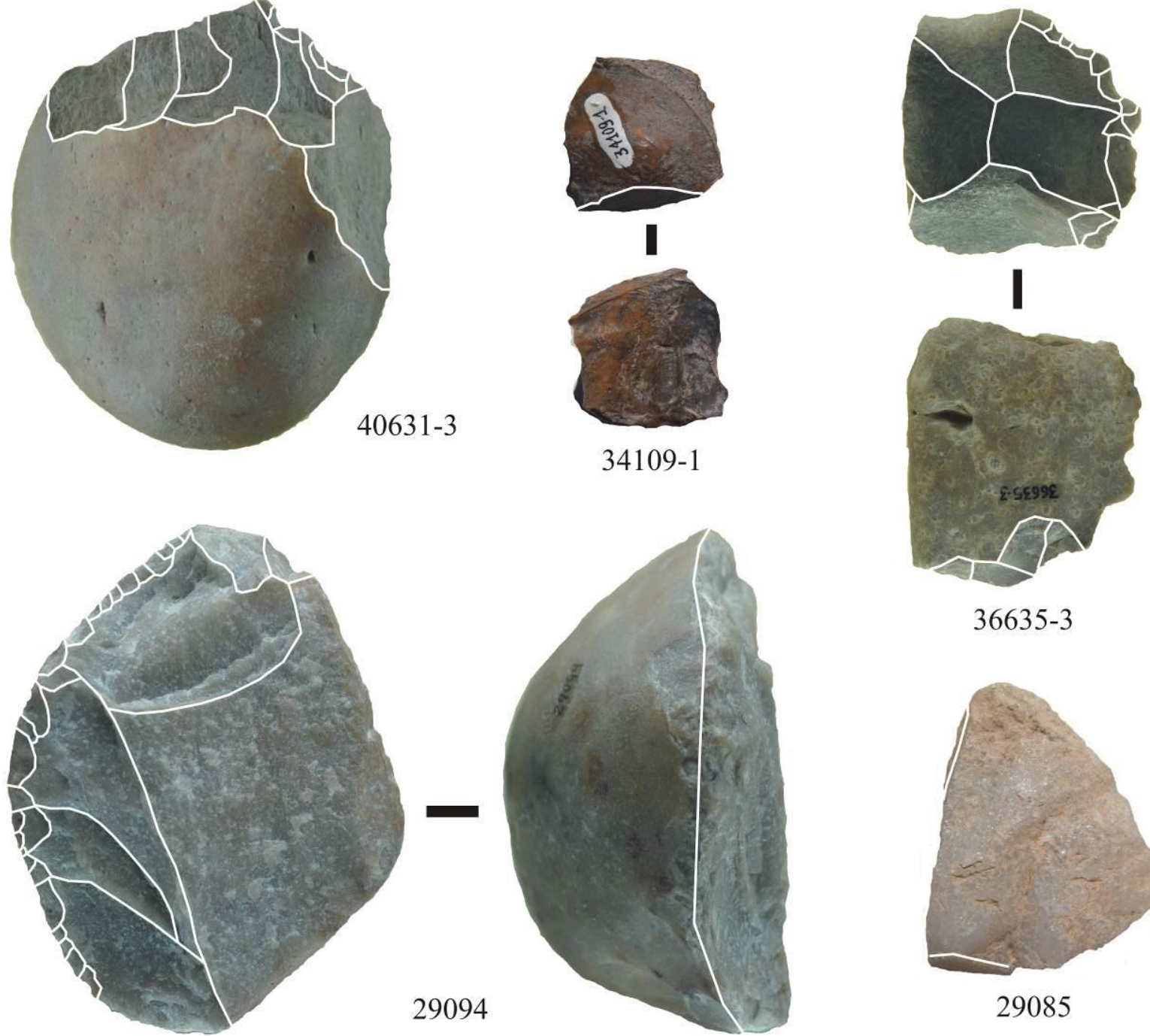

$36635-3$

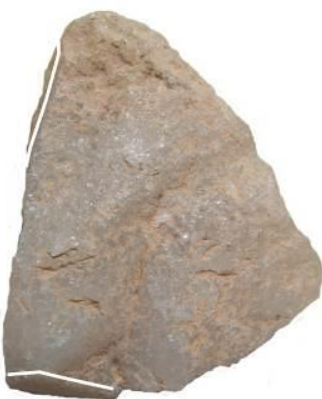

29085
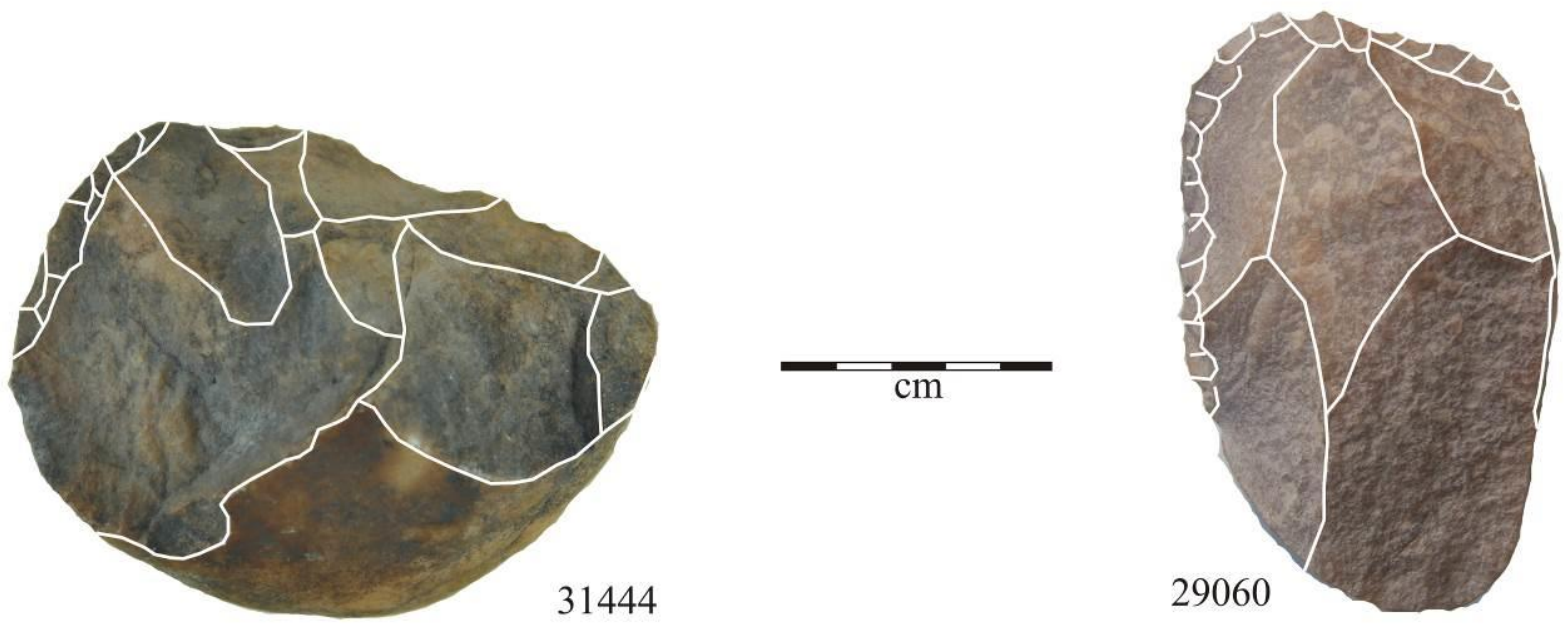

Figure 10. Artifacts from lower Holocene of Sitio do Meio, Serra Talhada I phase. Numbers refer to FUMDHAM inventory. 40631-3: chopper, 34109-1: flake, 36635-3: denticulate, 29094: simple scraper, 29085: flake, 31444: chopper, 29060: convex scraper. (Photo by L. Mota.) 


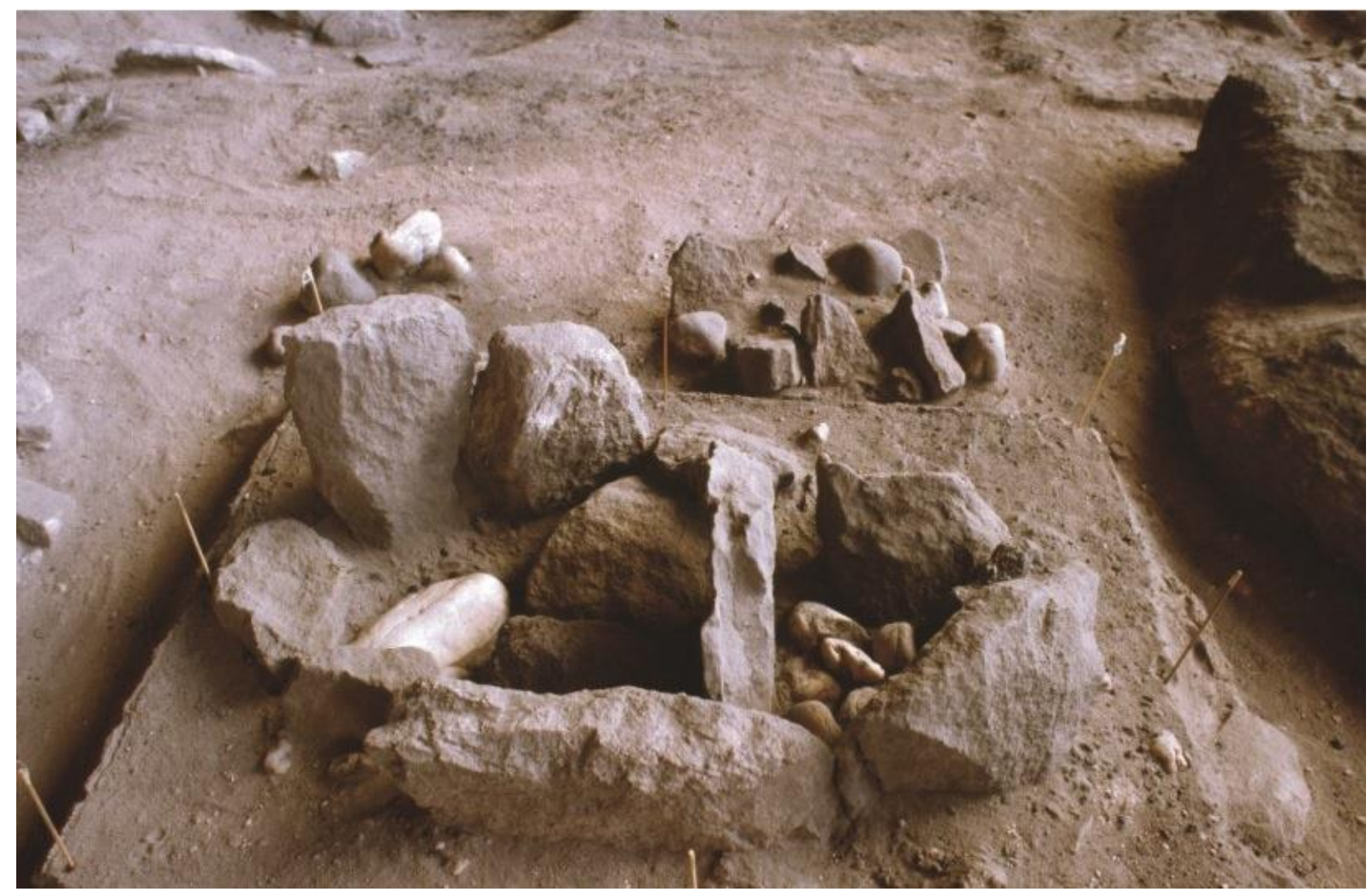

Figure 11. Hearth 32, sector 3, 8,804+/-53 (LY 10138) (Photo by Fumdham Archive)

A very peculiar and popular artifact from SDM is a kind of anvil, unifacial or bifacial, obtained from large siltstone slabs; 115 of them have been recovered, almost all in sector 2, and 77 attributed to Pleistocene layers (Pinheiro De Melo 2007). Optical analysis using a binocular microscope suggest they have been used as polishers or grinders for seeds, nuts and pigments, the last ones frequently recovered as red or yellow ochre. In this regard, parietal art at SDM (paintings and engravings) is attributed to the Nordeste tradition, dated to lower Holocene (Cisneiros 2008), based only on stylistic ground. Some figures have been engraved on fallen blocks after 8,100 \pm 90 years BP (GIF 9409). Finally it is worth mentioning that a polished axe in granodiorite has been described (Guidon \& Pessis 1993) as coming from a layer dated at 9,200 \pm 60 years BP, in sector 4 (Beta 65856) as well as a fragment of coarse

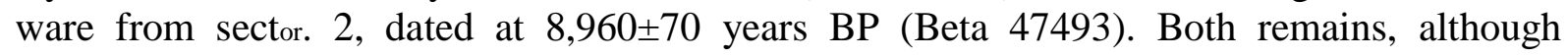
relevant, need to be considered with caution because of the complex stratigraphy of the site, as well as the problems associated to the documentation and field recording of the excavations.

Palaeoenvironmental data from SDM come from studies on palynological and faunal remains. Pollen has been obtained from 30 coprolites and the most relevant result (Chaves 1997) shows that, between 12,000 and 8,000 BP, vegetation was typical of Cerrado (arboreal savanna of northern South America), and around 7,000 BP a Caatinga formation (shrubby savanna, as the current one) took over, pointing for a moister climate at the PleistoceneHolocene transition. Because of the sediment acidity, faunal remains have been recovered only in the upper layers. They consist in about 2,150 remains of small mammals, very similar to the current faunal composition (Schmalz 1998). 


\section{Discussion and conclusion: Sitio do Meio in its context}

With regards to stone tools, it seems that SDM did not play the central function that BPF did in the regional settlement system. If the lithic industry in the last millennia of Pleistocene at SDM can be reliably compared only with that from BPF, between 11 and 8,000 BP, an overview at a macro-regional scale can be established. Both SDM and BPF share main technical traits of the Palaeoindian so-called Itaparica "tradition" of Brazilian Planalto, present on a wide area, from Goiás to Pernambuco states (Lourdeau 2010). This tradition has been characterized by generally unifacial flaking with occasional occurrence of bifacial projectile points, as observed in Lapa do Boquete, Santana do Riacho, Perna I, and BPF. In some cases, like SDM, Santana do Riacho and Sítio do Justino, bipolar flaking has been observed (Fogaça 2001).

In this context the palaeoanthropological evidence, for the period encompassed by SDM sequence, can be summarized as follows: 1) at the very end of the Pleistocene an archaic and robust human morphology is present in the region, as documented by the cranial and dental remains from Garrincho, a limestone cave just $15 \mathrm{~km} \mathrm{SW}$ from SDM (Peyre et al. 1998). The remains have been dated at 12,170 \pm 40 uncal. years BP (Beta 1366204), dating just after the first preserved occupations at SDM (Guidon et al. 2000); 2) at Toca do Paraguaio, another sandstone shelter close to SDM with funerary evidence, two penecontemporaneous burials (dated at 8,800-8,500 uncal. BP) presented two distinct cranial types, one of AustroMelanesian/African morphology and the other much more similar to present mongoloid forms (Bernardo \& Neves 2009). The authors of this study propose that in Lower Holocene two different human groups were present in Northern South America at the same time, probably the product of two different migration waves. This is exactly the period in which all the sites in the region show an impressive change regarding essential cultural traits such as lithic toolkit, rock-art and burials.

In this paper we presented the revision of the available information on the stratigraphy and archaeology of SDM, presenting analytical data on its lithic industries and showing that a considerable amount of evidence from the main sector can be reliably exploited. A minimum of about one hundred artifacts can be undoubtedly associated to the layers dated from the Late Pleistocene, deserving to be attentively considered in the debate about the earliest peopling of South America.

Just close to Pedra Furada, Sítio do Meio is the second archaeological Late Pleistocene site in North-Eastern Brazil with stone tools associated with structures. Just because the anthropic origin of BPF artifacts has been questioned, SDM is extremely important because of the absence of the main physical force pontentially creating geofacts in this kind of site, i.e. waterfalls. Certainly, we should have more data on the sedimentary history of the deposit and on the taphonomy of lower units, which could still be possible on sector 1 . The next research goal, in our opinion, should be the comparison of the artifact sample we presented here, surely Pleistocene in age, with both the artifacts recovered from Boeda team in 2012 and 2013 campaigns and the assemblage of PF3 phase of BPF, along with the toolkit from the recently published Vale da Pedra Furada and Tira Peia sites (Lahaye et al., 2013). For so doing, it is essential to adopt a common methodology and a clear-cut classificatory toolkit. In any case, SDM not only confirm the presence of humans in Northeastern Brazil well before the bewitched chronological boundary of the end of Pleistocene, but it also provides the first step for a systematic intra-site analysis of the Southern fringe of the Cuesta of Serra da Capivara.

\section{Acknowledgments}

The research and dissertations have been possible thanks to the collaboration of Niéde Guidon and Fundação Museu do Homem Americano (São Raimundo Nonato, Piaui, Brazil). 
The Italian Ministry of Foreign Affairs has partially funded the campaigns. Thanks to Astolfo Araujo for suggestions and to Mercedes Okumura for the revision of the English version and the two anonymous reviewers of the journal for useful and kind suggestions.

\section{References}

Aimola, G. 2008, L'industria Litica di Sitio do Meio (Piaui, Brasile): Ricerca del cambiamento culturale tra Pleistocene e Olocene nel Nord Est del Brasile, Dissertação de mestrado em Arqueologia, Universidade de Ferrara, Ferrara, 151p. (in Italian) (Master's thesis in Archaeology; "The lithic industries from Sitio do Meio (Piaui, Brazil): a research on culture change between Pleistocene and Holocene in the Northeastern Brazil")

Anderson, D.G., \& Gillam, J.C. 2000, Paleoindian Colonization of the Americas: Implications from an Examination of Physiography, Demography, and Artifact Distribution, American Antiquity, 65 (1): 43-66. Stable URL: http://www.jstor.org/stable/2694807

Andrade, C.A.S. 2010, Estruturas de Fogueira dos Sítios Arqueológicos do Parque Nacional Serra da Capivara e Entorno, Trabalho de Conclusão de Curso em Arqueologia e Preservação Patrimonial, Universidade Federal do Vale do São Francisco, São Raimundo Nonato, 107 p. (in Portuguese) (B.A. Dissertation in Archaeology and Heritage Management; "Hearth structures from archaeological sites of Serra da Capivara National Park and its surroundings")

Bernardo, D. V., \& Neves, W. A, 2009, Diversidade morfocraniana dos remanescentes ósseos humanos da Serra da Capivara: implicações para a origem do homem americano. FUMDHAMentos-Revista da Fundação Museu do Homem Americano, 8: 87-93. (in Portuguese) ("Morphocranial diversity from bone remains of Serra da Capivara: Implications for the origins of first Americans") URL: http://www.fumdham.org.br/fumdhamentos_8/artigos/Artigo_5_de_94_a_106.pdf

Boëda, E., Lourdeau, A., Lahaye, C., Daltrini Felice, G., Viana, S., Clemente-Conte, I., Pino, M., Fontugne, M., Hoeltz, S., Guidon, N., Pessis, A.-M., Da Costa, A., \& Pagli, M. 2013, The Late-Pleistocene Industries of Piauí, Brazil: New Data, in: Paleoamerican Odyssey, Edited by Kelly E. Graf, Caroline V. Ketron, and Michael R. Waters, Texas A\&M University Press: 445-465.

Bordes, F. 1975, Sur la notion de sol d'habitat en préhistoire paléolithique, Bulletin de la Société Préhistorique Française, 72: 139-143. (in French) ("On the concept of living floors in Palaeolithic prehistory").

Bryan, A. L., \& Gruhn, R. 2003, Some difficulties in modeling the original peopling of the Americas, Quaternary International, 109-110: 175-179. doi:10.1016/S10406182(02)00211-2

Chaves, S.A. 1997, Etude palynologique des coprolithes préhistoriqus holocèns recueillis sur les sites de "Toca do Boqueirão do Sítio da Pedra Furada", "Sítio do Meio" et "Sítio da Baixa do Cipó”. Apport paléoethnologique, paléoclimatique et paléoenvironmental pour la région Sud-Est du Piauí - Brésil, Ph.D. thesis, Museum National d'Histoire Naturelle, Paris. (in French) ("Palynological study of prehistoric coprolites from "Toca do Boqueirão do Sítio da Pedra Furada", "Sítio do Meio" et "Sítio da Baixa do Cipó". Palaeoetnological, palaeoclimatic and palaeoenvironmental contribution to SouthEastern Piaui-Brazil”) 
Chaves, S.A., Parenti, F., Guérin, C., Faure, M., Candelato, F., Rioda, V., Mengoli, D., Ferrari, S., Natali, L., Scardia, G. \& Oberlin, C. 2006, Palinologicals analyses of Quaternary lacustrine sediments from "Lagoa do Quari", NE Brazil (PI), FUMDHAMentos - Revista da Fundação Museu do Homem Americano, 7: 64-68. URL:

http:/ww.fumdham.org.br/pesquisas/paleontologia/2008\%20Chaves\%20et\%20al.pdf

Cisneiros, D. 2008, Similaridades e diferenças nas pinturas rupestres pré-históricas de contorno aberto no Parque Nacional Serra da Capivara - PI, Tese de Doutorado Programa de Pós-Graduação em Arqueologia, Universidade Federal de Pernambuco, Recife, 322 p. (in Portuguese) (Ph.D. Thesis in Archaeology; "Similarities and differences among open contour prehistoric rock paintings in the Serra da Capivara national Park")

Dillehay, T. D. 2008, Early Population Flows in the Western Hemisphere. In: A Companion to Latin American History (Holloway, T. H., ed.), Wiley-Blackwell, Oxford, p. 10-27. doi:10.1002/9781444391633.ch1

Fogaça, E. 2001. Mãos para o pensamento. A variabilidade tecnológica de indústrias líticas de caçadores-coletores holocênicos a partir de um estudo de caso: as camadas VIII e VII da Lapa do Boquete (Minas Gerais, Brasil - 12.000/10.500 B.P.), Tese de Doutoramento do Programa de Pós-Graduação em História, Pontifícia Universidade Católica do Rio Grande do Sul, Porto Alegre, 434p. (in Portuguese) (Ph.D. Thesis in History; "Hands for thought. Technological variability of Holocene hunther-gatherers lithic industries from a case study: layers VIII and VII from Lapa do Boquete (Minas Gerais, Brazil - 12.000/10.500 B.P.”)

Guérin, C., \& Faure, M. 2008, La biodiversité mammalienne au Pléistocène supérieur Holocène ancien dans la Région du Parc National Serra da Capivara (SE du Piauí, Brésil), FUMDHAMentos - Revista da Fundação Museu do Homem Americano, 7: 8093. (in French) ("Mammalian biodiversity in the Upper Pleistocene-Lower Holocene of Serra da Capivara National Park, SE Piaui, Brazil") URL:

http://www.fumdham.org.br/pesquisas/paleontologia/2008\%20Fumdhamentos\%20.pdf

Guidon, N., 1985, A arte pré-histórica da área arqueológica de São Raimundo Nonato: síntese de dez anos de pesquisa, Clio - Revista do Mestrado em História UFPE, 2: 3-80. (in Portuguese) ("Prehistoric rock-art from São Raimundo Nonato archaeological area: a synopsis of ten years research")

Guidon, N., \& Arnaud, M.B. 1991, The chronology of the New World: two faces of one reality, World Archaeology, 23 (2): 167-178. doi:10.1080/00438243.1991.9980169

Guidon, N., \& Andreatta, M.D. 1980, O sítio arqueológico Toca do Sítio do Meio (Piauí), Clio- Revista do Mestrado em História UFPE, 3: 7-29. (in Portuguese) ("The archeological site of Toca do Sítio do Meio (Piauí)")

Guidon, N., \& Delibrias G. 1986, Carbon-14 dates point to man in the Americas 32.000 years ago, Nature, 321 (6072): 769-771. doi:10.1038/321769a0

Guidon, N., \& Pessis, A.M. 1993, Recent discoveries on the holocenic levels of Sítio do Meio rock-shelter, Piauí, Brasil, Revista Clio- Série Arqueológica-UFPE, 9: 77-80.

Lahaye, C., Hernandez, M., Boëda, E., Felice, G.D., Guidon, N., Hoeltz, S., Lourdeau, A., Pagli, M., Pessis, A.M., Rasse, M., \& Viana, S. 2013, Human occupation in South 
America by 20,000 BC: the Toca da Tira Peia site, Piauí, Brazil. Journal of Archaeological Science, 40: 2840-2847. doi:10.1016/j.jas.2013.02.019

Lanata, J. L., L. Martino, A., Osella , A., \& Garcia-Herst, A., 2008. Demographic conditions necessary to colonize new spaces: The case for early human dispersal in the Americas. World Archaeology, 40:520-537. doi:10.1080/00438240802452890

Lourdeau, A. 2010, Le tecnocomplexe Itaparica. Définition techno-fonctionnelle des industries à pièces façonnées unifacialement à une face plane dans le centre et le Nordest du Brésil pendant la transition Pléistocène-Holocène et l'Holocène ancien. Tese de doutorado em meios, culturas e sociedades do passado e do presente, Université Paris Ouest Nanterre La Défense, Paris, 477p. (in French) (Ph.D. thesis; "Itaparica tecnocomplex. Technological and functional definition of unifacial industries in central and northeastern Brazil during Pleistocene-Holocene transition and lower Holocene")

Martin, G. 1997, Pré-História do Nordeste do Brasil. Editora Universitária da Recife, 450p. (in Portuguese) (Prehistory of Northeastern Brazil)

Meltzer, D. J., Adovasio, J. M., \& Dillehay, T. D. 1994, On a Pleistocene human occupation at Pedra Furada, Brazil. Antiquity, 68: 695-714. URL: http://antiquity.ac.uk/ant/068/Ant0680695.htm

Mota, L. A. 2010, Tecno-tipologia Lítica do Holoceno Inicial (9.450-8.100 anos BP) do Setor 2 do Sítio do Meio - Parque Nacional Serra da Capivara - PI. Trabalho de Conclusão de Curso em Arqueologia e Preservação Patrimonial, Universidade Federal do Vale do São Francisco, São Raimundo Nonato, 87p. (in Portuguese) (Master thesis in Archaeoogy; "Lithic techno-typology from lower Holocene (9.450-8.100 years BP) of Sector 2 of Sítio do Meio - Serra da Capivara National Park - PI”)

Parenti, F. 2001, Le gisement quaternaire de la Pedra Furada (Piaui, Brésil): Stratigraphie, chronologie, evolution culturelle. Ed. Recherches sur les Civilisations, Paris, 312p. (in French) ("The Quaternary site of Pedra furada (Piaui, Brazil): Stratigraphy, chronology, cultural evolution")

Parenti, F., Fontugne, M. \& Guérin, C. 1996, Pedra Furada in Brazil, and its "presumed" evidence: limitations and potential of the available data. Antiquity, 70: 416-421. URL: http://antiquity.ac.uk/ant/070/Ant0700416.htm

Perego, U. A., Achilli, A., Angerhofer, N., Accetturo, M., Pala, M., Olivieri, A., Kashani, B.H., Ritchie, K.H., Scozzari, R., Kong,Q.P., Myres, N.M., Salas, A., Semino, O., Bandelt, H.J., Woodward, S.R., \& Torroni, A. 2009, Distinctive Paleo-Indian Migration Routes from Beringia Marked by Two Rare mtDNA Haplogroups. Current Biology, 19 (1): 1-8. doi:10.1016/j.cub.2008.11.058

Peyre, E., Guerin, C., Guidon, N., \& Coppens, Y. 1998, Des restes humains pléistocènes dans la grotte du Garrincho, Piaui, Brésil. Comptes Rendus de l'Académie des Sciences de Paris, 327: 355-360. (in French) ("Pleistocene human remains from Garrincho cave, Piaui, Brazil”)

Pinheiro De Melo, P. 2000, Arqueologia Experimental: os blocos com marcas de uso do Sítio do Meio - PARNA Serra da Capivara - PI - BR. Revista Clio-Série ArqueológicaUFPE, 1: 143-159. (in Portuguese) ("Experimental archaeology: utilized blocks from Sítio do Meio - Serra da Capivara National Park, Piaui, Brazil”)

Pinheiro De Melo, P. 2007, A transição do Pleistoceno ao Holoceno no Parque Nacional Serra da Capivara - Piaui - Brasil: uma contribuição ao estudo sobre a antiguidade da 
presença humana no sudeste do Piaui. Tese de doutorado em História, Universidade Federal do Pernambuco, Recife, 376p. (in Portuguese) (Ph.D. thesis in History; "Pleistocene-Holocene transition in the Serra da Capivara national park - PiauiBrazil: a contribution to the study of human presence in Southeastern Piaui")

Pitblado, B. L. 2011, A Tale of Two Migrations: Reconciling Recent Biological and Archaeological Evidence for the Pleistocene Peopling of the Americas. Journal of Archaeological Research, 19 (4): 327-375. doi:10.1007/s10814-011-9049-y

Santos, G.M., Bird, M.I., Parenti, F., Fifield, L.K., Guidon, N., \& Hausladen, P.A. 2003, A revised chronology of thelowest occupation layer of Pedra Furada Rock Shelter, Piaui, Brazil: the Pleistocene peopling of the Americas. Quaternary Science Reviews, 22: 2303-2310. doi:10.1016/S0277-3791(03)00205-1

Santos, J. C. 2007, O Quaternário do Parque Nacional Serra da Capivara e entorno, Piauí, Brasil: morfoestratigrafia, sedimentologia, geocronologia e paleoambientes. Tese de doutorado em Geociências, Universidade Federal de Pernambuco, Recife, 171p. (in Portuguese) (Ph.D. thesis in Geosciences; "The Quaternary of Serra da Capivara National Park and surrondings, Piaui, Brazil: morphostratigraphy, sedimentology, geochronology and palaeoenvironments")

von Schmalz, K. E. 1998, A Toca do Sítio do Meio: Coleção microfaunística. Relatório apresentado a FUMDHAM, São Raimundo Nonato. (in Portuguese) ("Sitio do Meio rock-sheltes: Microfaunal assemblage") 